\title{
Characterization of extended-spectrum $\beta$-lactamase-producing Escherichia coli and Klebsiella pneumoniae isolates from the community in Morocco
}

Correspondence

Mohammed Timinouni mohammed.timinouni@ pasteur.ma

Received 24 March 2011 Accepted 2 May 2011

\author{
Abouddihaj Barguigua, ${ }^{1,2}$ Fatima El Otmani, ${ }^{2}$ Mustapha Talmi, ${ }^{2}$ \\ Fatna Bourjilat, ${ }^{1}$ Fatima Haouzane, ${ }^{1,2}$ Khalid Zerouali ${ }^{3}$ \\ and Mohammed Timinouni ${ }^{1}$ \\ ${ }^{1}$ Molecular Bacteriology Laboratory, Pasteur Institute of Morocco, Casablanca, Morocco \\ ${ }^{2}$ Microbiology, Health and Environment Team, Department of Biology, School of Sciences, Chouaib \\ Doukkali University, El Jadida, Morocco \\ ${ }^{3}$ University Hospital Center, Ibn Rochd, Casablanca, Morocco
}

Of 803 community Escherichia coli $(n=767)$ and Klebsiella pneumoniae $(n=36)$ isolates collected from patients with urinary tract infections in three Moroccan cities, $10 \mathrm{E}$. coli (1.3\%) and $2 \mathrm{~K}$. pneumoniae $(5.6 \%)$ isolates were shown to produce extended-spectrum $\beta$-lactamases (ESBLs). PFGE revealed that the $E$. coli isolates comprised seven distinct genotypes. The presence of plasmids in the 12 isolates was revealed by conjugation experiments of plasmids from these Enterobacteriaceae strains with $E$. coli $\mathrm{K}_{12} J_{5}$, with further isolation of the plasmids in the transconjugants. Subsequent nucleotide sequencing indicated that the plasmids encoded the bla $a_{\mathrm{CTX}-\mathrm{M}}$, bla OXA, bla $a_{\mathrm{TEM}}$ and bla $\mathrm{SHV}_{\mathrm{SHV}}$ genes, including genes for CTX-M-15 $(n=11), \mathrm{OXA}-1$ $(n=11)$, TEM-1b $(n=4)$, SHV-5 $(n=1)$ and SHV-1 $(n=2)$. Identification of plasmid-mediated quinolone-resistance genes was performed by PCR. The aac $\left(6^{\prime}\right) / b$-cr variant was detected in all strains, and two strains co-expressed qnrS1, b/a $a_{\mathrm{CTX}-\mathrm{M}-15}$ and b/aOXA-1 genes. The presence of ESBLs in the Enterobacteriaceae strains studied was probably due to the dissemination of resistance plasmids with the predominant genotype of bla

\section{INTRODUCTION}

Extended-spectrum $\beta$-lactamases (ESBLs) are enzymes that compromise the efficacy of all $\beta$-lactams, except cephamycins and carbapenems, by hydrolysis of the $\beta$-lactam ring, and are inhibited by $\beta$-lactamase inhibitors (Coque et al., 2008). There are more than 400 ESBLs described so far, most derived from the groups TEM, SHV and CTX-M, with 183,134 and 103 variants, respectively (http://www. lahey.org/Studies/).

Since the early 2000s, CTX-M-type ESBLs have been increasingly reported, and these enzymes have now replaced TEM and SHV as the most common type of ESBL. The genes encoding ESBLs are usually located on plasmids that are highly mobile and can harbour resistance genes to several other unrelated classes of antimicrobials (Baudry et al., 2009), such as the plasmid-mediated quinolone-resistance

Abbreviations: DDST, double-disc synergy test; ESBL, extendedspectrum $\beta$-lactamase; PFP, pulsed-field profiles; PMOR, plasmidmediated quinolone resistance.
(PMQR) genes and aminoglycoside-resistance genes (Crémet et al., 2011; Rodríguez-Baño et al., 2009).

CTX-M enzymes, particularly CTX-M-15, have been involved in various epidemiological situations and have disseminated throughout all continents as a result of epidemic plasmids and/or particular epidemic strains (Ruppé, 2010). CTX-M-producing Escherichia coli and Klebsiella pneumoniae are becoming increasingly involved in urinary tract infections, especially among outpatients. Furthermore, these bacteria seem to have been imported from the community into the hospital setting (Arpin et al., 2009).

Some studies have shown a high prevalence of ESBLproducing Enterobacteriaceae in hospitals in North African countries (Iabadene et al., 2008; Sekhsokh et al., 2008), including Morocco (Lahlou Amine et al., 2009; Sekhsokh et al., 2008). However, little information is available regarding their prevalence within the community. In 2004, a survey conducted on antibiotic resistance in community E. coli strains isolated from various specimens collected in Casablanca (Morocco) revealed that ESBL 
producers were detected at a rate of $1.3 \%$ (Bourjilat et al., 2009). Until recently, no data were available regarding the types and frequency of ESBLs in Moroccan communities. In this study, we investigated the dissemination of these enzymes among community E. coli and $K$. pneumoniae strains responsible for urinary tract infections. The antimicrobial-resistance profiles, the presence and transferability of resistance genes, and the genetic diversity of these isolates were also investigated.

\section{METHODS}

Bacterial isolates. In this study, 767 E. coli and $36 \mathrm{~K}$. pneumoniae non-repeated strains isolated from patients suffering from community-acquired urinary tract infections were studied. The strains were collected from the medical analysis laboratories of three Moroccan cities: Casablanca, situated in the centre of the Atlantic coast of Morocco; El Jadida, located $100 \mathrm{~km}$ south west of Casablanca; and Settat, situated $72 \mathrm{~km}$ south of Casablanca. The isolates were collected from September 2004 to November 2009.

Antimicrobial drug susceptibility testing and ESBL detection. Antimicrobial drug susceptibility was determined by a disc-diffusion method on Mueller-Hinton ( $\mathrm{MH}$ ) agar plates (Bio-Rad), according to the recommendations of the Antibiogram Committee of the French Society for Microbiology (http://www.sfm-microbiologie.org). The following antimicrobial agents were tested: amoxicillin $(10 \mu \mathrm{g})$, amoxicillin/clavulanic acid $(20 / 10 \mu \mathrm{g})$, cefoxitin $(30 \mu \mathrm{g})$, cefotaxime $(30 \mu \mathrm{g})$, ceftazidime $(30 \mu \mathrm{g})$, cefepime $(30 \mu \mathrm{g})$, imipenem $(10 \mu \mathrm{g})$, aztreonam $(30 \mu \mathrm{g})$, nalidixic acid $(30 \mu \mathrm{g})$, ciprofloxacin $(5 \mu \mathrm{g})$, gentamicin $(10 \mu \mathrm{g})$, tobramycin $(10 \mu \mathrm{g})$, kanamicin $(30 \mu \mathrm{g})$, amikacin $(30 \mu \mathrm{g})$, trimethoprim/sulfamethoxazole $(1.25 / 23.75 \mu \mathrm{g})$ and tetracycline $(30 \mu \mathrm{g})$. Quality control was conducted using the reference strain E. coli ATCC 25922.

ESBL production was screened using a double-disc synergy test (DDST) as a standard disc-diffusion assay on $\mathrm{MH}$ agar. Discs containing aztreonam $(30 \mu \mathrm{g})$, ceftazidime $(30 \mu \mathrm{g})$, cefepime $(30 \mu \mathrm{g})$ and cefotaxime $(30 \mu \mathrm{g})$ were placed at a distance of $30 \mathrm{~mm}$ (centre to centre) around a disc containing amoxicillin/clavulanic acid (20/ $10 \mu \mathrm{g}$ ), as recommended by the Antibiogram Committee of the French Society for Microbiology (http://www.sfm-microbiologie.org). Isolates that were DDST negative and resistant to third-generation cephalosporins were screened for an ESBL phenotype using an $\mathrm{ESBL}+\mathrm{AmpC}$ screening identification kit (Rosco Diagnostic) according to the manufacturer's instructions.

Preparation of DNA template for PCR. DNA templates for PCR were generated by suspending five colonies of an overnight growth of Enterobacteriaceae isolates on Luria-Bertani agar (Bio-Rad) in $500 \mu \mathrm{l}$ DNase- and RNase-free water (Invitrogen). The suspension was boiled at $100^{\circ} \mathrm{C}$ for $10 \mathrm{~min}$ in a thermal block (Polystat 5; Bioblock Scientific), then centrifuged at $19000 \mathrm{~g}$ for $5 \mathrm{~min}$. An aliquot of $1 \mu \mathrm{l}$ of the supernatant was used as DNA template for PCR.

Detection of $\boldsymbol{\beta}$-lactamase-encoding genes. Enterobacteriaceae isolates included in the study were screened by PCR for the following $\beta$-lactamase-encoding genes: $b l a_{\mathrm{CTX}-\mathrm{M}}$ phylogenetic lineage groups 1 , 2 and $9, b l a_{\mathrm{TEM}}, b l a_{\mathrm{SHV}}, b l a_{\mathrm{OXA}-1}, b l a_{\mathrm{PER}}$ and $b l a_{\mathrm{VEB}}$, as described by Guessennd et al. (2008).

For all $\beta$-lactamase detection methods, the known $\beta$-lactamaseproducing strains E. coli U2A1790 (CTX-M-1), E. coli U2A1799 (CTX-M-9), Salmonella sp. U2A2145 (CTX-M-2), Salmonella sp. U2A1446 (TEM-1 and SHV-12), Pseudomonas aeruginosa U2A1125
(PER), Acinetobacter baumannii U2A2026 (VEB) and E. coli U2A2446 (OXA-1) were used as positive controls. E. coli $\mathrm{K}_{12} \mathrm{~J}_{5}$ strain was used as a negative control.

Detection of PMQR genes associated with ESBL genes. All ESBL-producing strains were screened by multiplex PCR for $q n r$ genes ( $q n r A$, $q n r B$ and $q n r S)$ as described by Guessennd et al. (2008), and for $a a c\left(6^{\prime}\right)-I b$ and $q e p A$ genes as described by Périchon et al. (2007). The PMQR-producing E. coli strains U2A1528 [aac(6')-Ib], U2A2118 (qnrA1), U2A2119 (qnrB1) and U2A2120 ( $q n r S 1$ ), and E. coli TOP10/pAT791 (qepA) were used as positive controls. The primers used in this work are shown in Table 1.

Sequencing of ESBL and PMQR genes. All amplified products were sequenced to validate their identities. Both strands of the purified amplicons were sequenced with a Genetic Analyzer 3130x1 sequencer (Applied Biosystems), using the same primers as used for PCR amplification. Nucleotide and deduced protein sequences were analysed with software available from the National Center for Biotechnology Information (http://www.ncbi.nlm.nih.gov).

Conjugation experiments and plasmid analysis. Conjugation assays were performed using a broth mating method with an azideresistant mutant of $E$. coli $\mathrm{K}_{12} \mathrm{~J}_{5}$ as the recipient strain. Transconjugants were selected on $\mathrm{MH}$ agar containing azide (200 $\left.\mathrm{mg} \mathrm{l}^{-1}\right)$ and ceftazidime $\left(2 \mathrm{mg} \mathrm{l}^{-1}\right)$ (Bio-Rad), and incubated for $18-24 \mathrm{~h}$ at $37^{\circ} \mathrm{C}$. If not successful at the first attempt, mating experiments were repeated up to three times.

The putative transconjugants were tested for their susceptibility to all 16 antibiotics to identify transferable antibiotic-resistance determinants. MICs of $\beta$-lactams (cefotaxime, ceftazidime, and cefepime), quinolones (nalidixic acid, ciprofloxacin and levofloxacin) and aminoglycosides (gentamicin, tobramycin, kanamicin and amikacin) were determined using the Etest method (AB Biodisk) for ESBLcarrying strains and their transconjugants.

Plasmid DNA extraction from donors and transconjugants was performed using a plasmid midi prep kit (Qiagen) according to manufacturer's instructions. The sizes of plasmids were estimated by electrophoresis on $0.7 \%$ agarose gels using plasmids from E. coli V517 as the standard markers (Macrina et al., 1978).

PFGE. PFGE was performed to determine the genetic relatedness among the E. coli isolates, following a standardized protocol developed by Durmaz et al. (2009) using XbaI. The Dice similarity coefficient was calculated between pairs of lanes, and the strains were grouped using UPGMA, using the dendrogram construction utility DendroUPGMA (Biochemistry and Biotechnology Department, Rovira i Virgili University, Tarragona, Spain) (http://genomes.urv. cat/UPGMA/index.php).

\section{RESULTS}

Among the E. coli $(n=767)$ and K. pneumoniae $(n=36)$ isolates studied, 37 and 8 , respectively, were resistant to third-generation cephalosporins. Screening using the DDST and ESBL + AmpC identification kit revealed that only ten E. coli (1.3\%) and two K. pneumoniae (5.6\%) were ESBL producers.

The antimicrobial-resistance patterns of the 12 ESBLproducing isolates are shown in Table 2. All isolates were multidrug resistant but were susceptible to imipenem and cefoxitin. We observed a substantial level of resistance to 
Table 1. Primers used for PCR amplification and sequencing

\begin{tabular}{|c|c|c|c|c|}
\hline Gene & Primer & Primer sequence $\left(5^{\prime} \rightarrow 3^{\prime}\right)$ & Amplicon (bp) & Reference \\
\hline \multirow[t]{2}{*}{$b l a_{\text {СтХ-M group } 1}$} & CTX-M1(+) & GGTTAAAAAATCACTGCGTC & 863 & Guessennd et al. (2008) \\
\hline & CTX-M1(-) & TTGGTGACGATTTTAGCCGC & & \\
\hline \multirow[t]{2}{*}{$b l a_{\text {СTX-M group2 }}$} & CTX-M2(+) & ATGATGACTCAGAGCATTCG & 865 & Guessennd et al. (2008) \\
\hline & CTX-M2(-) & TGGGTTACGATTTTCGCCGC & & \\
\hline \multirow[t]{2}{*}{$b l a_{\text {СTX-M group9 }}$} & CTX-M9(+) & ATGGTGACAAAGAGAGTGCA & 869 & Guessennd et al. (2008) \\
\hline & CTX-M9(-) & CCCTTCGGCGATGATTCTC & & \\
\hline \multirow[t]{2}{*}{$b l a_{\mathrm{TEM}}$} & $a-216$ & ATAAAATTCTTGAAGACGAAA & 1079 & Guessennd et al. (2008) \\
\hline & a-217 & GACAGTTACCAATGCTTAATCA & & \\
\hline \multirow[t]{2}{*}{$b l a_{\mathrm{SHV}}$} & Os-5 & CGCCGGGTTATTCTTATTTGTCGC & 795 & Guessennd et al. (2008) \\
\hline & Os-6 & CGCCGGGTTATTCTTATTTGTCGC & & \\
\hline \multirow[t]{2}{*}{$b l a_{\mathrm{OXA}-1}$} & Oxa-1 & CCAAAGACGTGG & 440 & Guessennd et al. (2008) \\
\hline & Oxa-2 & GTTAAATTCGACCCCAAGTT & & \\
\hline \multirow[t]{2}{*}{$b l a_{\mathrm{PER}}$} & $\operatorname{per}(+)$ & CCTGACGATCTGGAACCTTT & 716 & Guessennd et al. (2008) \\
\hline & $\operatorname{per}(-)$ & GCAACCTGCGCAAT(GA)ATAGC & & \\
\hline \multirow[t]{2}{*}{$b l a_{\mathrm{VEB}}$} & veb $(+)$ & ATTTCCCGATGCAAAGCGT & 542 & Guessennd et al. (2008) \\
\hline & $\operatorname{veb}(-)$ & TTATTCCGGAAGTCCCTGT & & \\
\hline \multirow[t]{2}{*}{$q n r A$} & $\operatorname{qnrA}(+)$ & TTCTCACGCCAGGATTTGAG & 571 & Guessennd et al. (2008) \\
\hline & $\mathrm{qnrA}(-)$ & TGCCAGGCACAGATCTTGAC & & \\
\hline \multirow[t]{2}{*}{$q n r B$} & $\mathrm{qnrB}(+)$ & TGGCGAAAAAAATT(GA)ACAGAA & 594 & Guessennd et al. (2008) \\
\hline & $\mathrm{qnrB}(-)$ & GAGCAACGA(TC)GCCTGGTAG & & \\
\hline \multirow[t]{2}{*}{$q n r S$} & $\mathrm{qnrS}(+)$ & GACGTGCTAACTTGCGTGAT & 388 & Guessennd et al. (2008) \\
\hline & qnrS $(-)$ & AACACCTCGACTTAAGTCTGA & & \\
\hline \multirow[t]{2}{*}{ qерA } & qepA $(+)$ & TGGTCACGCCATGGACCTCA & 1137 & Périchon et al. (2007) \\
\hline & qepA $(-)$ & TGAATTCGGACACCGTCTCCG & & \\
\hline \multirow[t]{2}{*}{$a a c\left(6^{\prime}\right)-I b$} & $\operatorname{aac}\left(6^{\prime}\right)-\mathrm{Ib}(+)$ & ATGACTGAGCATGACCTTG & 476 & Périchon et al. (2007) \\
\hline & $\operatorname{aac}\left(6^{\prime}\right)-\operatorname{Ib}(-)$ & AACCATGTACACGGCTGG & & \\
\hline
\end{tabular}

quinolones: the majority of the isolates (91.6\%) were resistant to nalidixic acid, except for E.c4. Cotrimoxazole resistance was observed in all strains except one $K$. pneumoniae (K.p30). All strains were resistant to at least one of the four aminoglycosides tested. The most frequently observed phenotypic profile included resistance to gentamicin and tobramycin (11/12 isolates). Three strains (E.c1, E.c9 and E.c64) were resistant to kanamycin and none was resistant to amikacin. Only four strains were resistant to tetracycline.

The results of ESBL-encoding gene detection by PCR revealed that the E. coli and $K$. pneumoniae strains harboured a diversity of $\beta$-lactamases, namely SHV, CTX-M, OXA and TEM enzymes, and that bla $a_{\mathrm{PER}}$ and $b l a_{\mathrm{VEB}}$ were not detected in any of the isolates (Table 2). Further analysis of the $b l a_{\mathrm{TEM}}$ sequences indicated that these Enterobacteriaceae harboured the TEM-1b subgroup, whereas for $b l a_{\mathrm{SHV}}$, the subgroup found in the isolates was

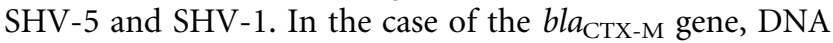
sequence analysis indicated that 11 isolates were carriers of the subgroup CTX-M-15 and no amplicons were obtained for the other two tested CTX-M subgroups. For bla $a_{\text {OXA }}$, the subgroup found in the isolates was OXA-1 (Table 2). All isolates except E.c1 harboured the CTX-M-15 gene associated with the $b l a_{\mathrm{OXA}-1}$ gene. The $b l a_{\mathrm{SHV}-5}$ and $b l a_{\mathrm{SHV}-1}$ genes were detected in one E. coli strain (E.c1) and two K. pneumoniae strains, respectively. The $b l a_{\mathrm{TEM}}$ gene was harboured by one K. pneumoniae and three E. coli isolates. All combinations of bla genes detected are shown in Table 2. Of the $11 b l a_{\mathrm{CTX}-\mathrm{M}}$ isolates, three also harboured $b l a_{\mathrm{TEM}}$ and two had $b l a_{\mathrm{SHV}}$. It is interesting to note that four $\beta$-lactamases genes were co-expressed in K. pneumoniae isolate K.p18: $b l a_{\mathrm{SHV}}, b l a_{\mathrm{OXA}}, b l a_{\mathrm{TEM}}$ and $b l a_{\mathrm{CTX}-\mathrm{M}}$. None of the 12 isolates carried the qepA, qnrA or $q n r B$ genes, whereas the $a a c\left(6^{\prime}\right)-I b-c r$ variant gene was detected in all isolates, two of which (E.c64 and K.p18) also harboured the qnrS1 gene (Table 2).

Conjugation experiments were carried out for all ESBL producers, but transfer of this phenotype to the recipient sodium azide-resistant E. coli $\mathrm{K}_{12} \mathrm{~J}_{5}$ was successful in only seven isolates (Table 3 ). All transconjugants were resistant to $\beta$-lactam and gentamicin. Kanamycin resistance was cotransferred in the Tc1, Tc9 and Tc64 transconjugants, whereas for the Tc64 transconjugant, trimethoprim, sulfamethaxazole and tetracycline resistances were also transferred (Table 3).

Plasmids of variable sizes were detected (Table 2): a plasmid of $\sim 125 \mathrm{~kb}$ was detected in $75 \%$ (9/12) of the isolates tested, and was always found with the CTX-M-15 ESBL type and OXA-1. All transconjugants had plasmids of $125 \mathrm{~kb}$ (Table 3).

The E.cl isolate successfully transferred the $b l a_{\mathrm{SHV}-5}$ and $b l a_{\mathrm{TEM}-1 \mathrm{~b}}$ genes to the E. coli $\mathrm{K}_{12} \mathrm{~J}_{5}$ recipient strain. These 
Table 2. Characteristics of the ESBL-producing enterobacteria strains studied

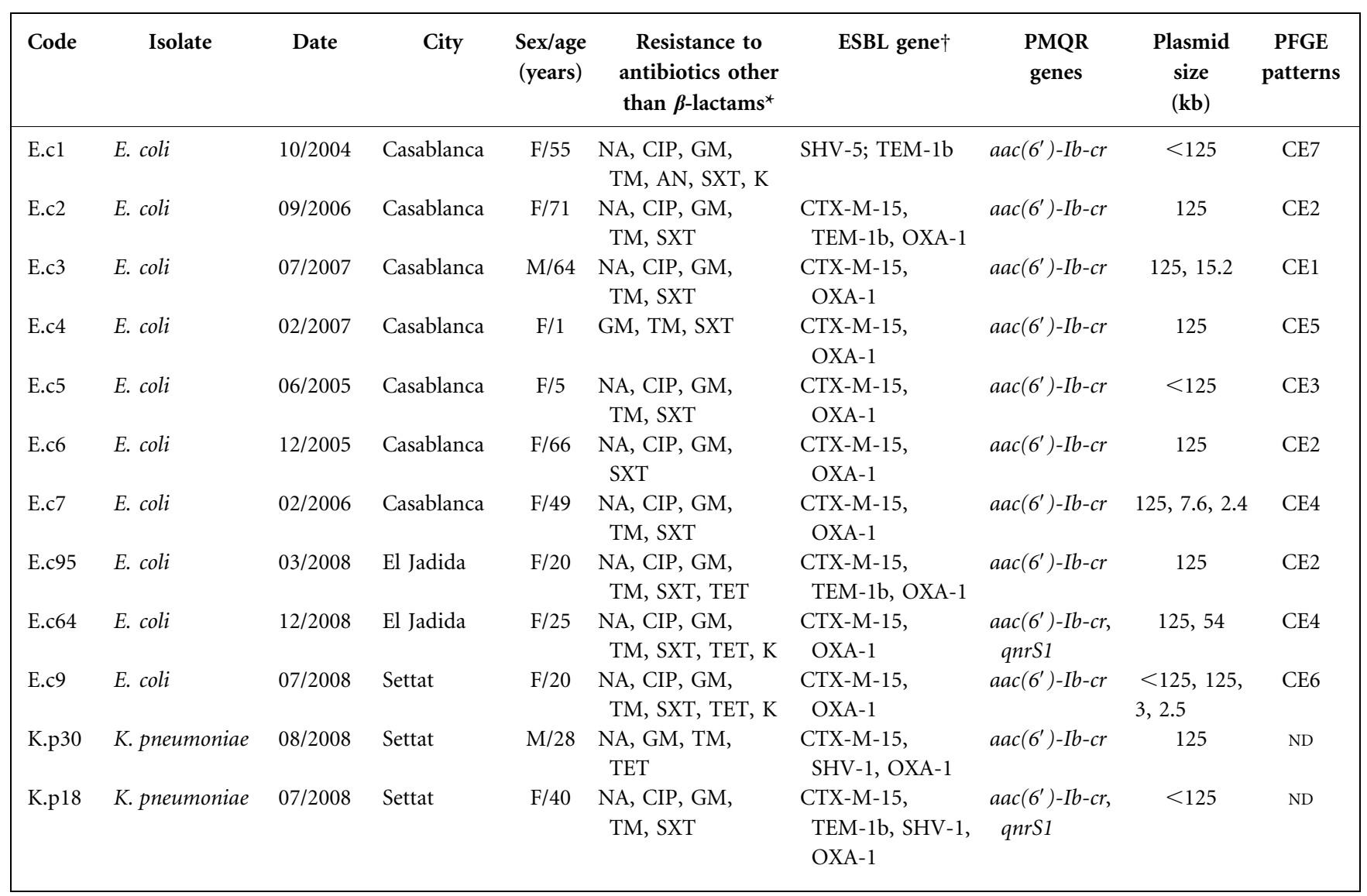

AN, Amikacin; CIP, ciprofloxacin; F, female; GM, gentamicin; M, male; NA, nalidixic acid; ND, not done; SXT, trimethoprim/sulfamethoxazole; TET, tetracycline; TM, tobramycin.

*All strains were susceptible to the imipenem and cefoxitin, and all were resistant to ampicillin, cefotaxime, ceftazidime and amoxicillin/clavulanic acid. $\dagger$ TEM-1b, OXA- 1 and SHV-1 are not ESBLs.

genes were carried by one conjugative plasmid of high molecular mass $(\sim 125 \mathrm{~kb})$. The E.c64 isolate contained two plasmids of $\sim 125$ and $\sim 54 \mathrm{~kb}$. In conjugation experiments, the E.c64 isolate transferred successfully $\beta$-lactam and fluoroquinolone resistance to the $E$. coli $\mathrm{K}_{12} \mathrm{~J}_{5}$ recipient strain. PCR and sequencing confirmed that the transconjugant carried the $q n r S 1, a a c\left(6^{\prime}\right)-I b-c r, b l a_{\text {OXA-1 }}$ and $b a_{\mathrm{CTX}-\mathrm{M}-15}$ genes on the large plasmid $(\sim 125 \mathrm{~kb})$.

Among the E. coli isolates, seven different pulsed-field profiles (PFPs) were identified and classified as PFP types CE1-CE7 (Fig. 1). The patterns CE1, CE3, CE5, CE6 and CE7 were represented by only one isolate. PFP type CE2 was prevalent, containing three $E$. coli isolates, and two subtypes were further determined within this PFP type, CE2a and CE2b, showing $88 \%$ similarity. The CE2b subtype was composed of two E. coli strains (E.c6 and E.c95) with high-level similarity (95\%); these strains were collected in two different community settings (Casablanca and El Jadida). Pattern CE4 comprised two isolates (E.c7 and E.c64) showing 100\% similarity, isolated from different outpatients clinics and were obtained in different years (2006 and 2008, respectively).

\section{DISCUSSION}

Enterobacteriaceae have become one of the most important causes of nosocomial and community-acquired infections. $\beta$-Lactams (mainly extended-spectrum cephalosporins and carbapenems) and fluoroquinolones constitute the main therapeutic choices to treat infections caused by these microorganisms. However, resistance to these compounds has been reported increasingly frequently from different parts of the world in recent years (Cantón et al., 2008; Reinert et al., 2007). The last European Antibiotic Resistance Surveillance System (http://www.ecdc.europa.eu/en/ activities/surveillance/EARS-Net) report from 2006, covering over 800 laboratories from 31 countries, showed a continuous increase since 2000 in invasive E. coli and $K$. pneumoniae isolates resistant to third-generation cephalosporins, with a prevalence of $>10 \%$ for half of the enrolled countries.

In our study, we found $37 / 767(4.8 \%)$ E. coli and $8 / 36$ (22.2\%) K. pneumoniae strains tested to be resistant to third-generation cephalosporins, but only 10 (1.3\%) E. coli 
Table 3. Characteristics of clinical strains and their transconjugants

\begin{tabular}{|c|c|c|c|c|c|c|c|c|c|c|c|c|c|c|c|}
\hline \multirow[t]{2}{*}{ Code } & \multirow[t]{2}{*}{ Species } & \multicolumn{10}{|c|}{$\operatorname{MICs}\left(\mu \mathrm{g} \mathrm{ml}^{-1}\right)$} & \multicolumn{2}{|c|}{ Transfer } & \multicolumn{2}{|c|}{ Genes } \\
\hline & & LEV & NA & CIP & GM & $\mathbf{T M}$ & AN & K & CTX & CAZ & FEP & $\begin{array}{c}\text { Resistance } \\
\text { profile other } \\
\text { than } \beta \text {-lactams }\end{array}$ & $\begin{array}{c}\text { Plasmid } \\
(\mathbf{k b})\end{array}$ & ESBL $^{\star}$ & PMQR \\
\hline E.c4 & E. coli & 0.032 & 8 & 1 & 48 & 32 & 8 & 1 & $>256$ & 16 & $>256$ & GM-TM & 125 & $\begin{array}{l}\text { CTX-M15, } \\
\text { OXA-1 }\end{array}$ & $a a c\left(6^{\prime}\right)-I b-c r$ \\
\hline Tc4 & E. coli & 0.02 & 2 & 0.02 & 8 & 16 & 3 & 0.064 & 24 & 24 & 96 & & & $\begin{array}{l}\text { CTX-M15, } \\
\text { OXA-1 }\end{array}$ & $a a c\left(6^{\prime}\right)-I b-c r$ \\
\hline E.c5 & E. coli & 6 & $>256$ & 32 & 16 & 12 & 6 & 64 & $>256$ & 8 & 64 & GM & 125 & $\begin{array}{l}\text { CTX-M15, } \\
\text { OXA-1 }\end{array}$ & $a a c\left(6^{\prime}\right)-I b-c r$ \\
\hline Tc5 & E. coli & 0.012 & 2 & 0.25 & 12 & 2 & 3 & 0.094 & 8 & 48 & $>256$ & & & $\begin{array}{l}\text { CTX-M15, } \\
\text { OXA-1 }\end{array}$ & $a a c\left(6^{\prime}\right)-I b-c r$ \\
\hline E.c7 & E. coli & 0.032 & 4 & 0.5 & 64 & 16 & 6 & 2 & $>256$ & 48 & 128 & TM & 125 & $\begin{array}{l}\text { CTX-M15, } \\
\text { OXA-1 }\end{array}$ & $a a c\left(6^{\prime}\right)-I b-c r$ \\
\hline Tc7 & E. coli & 0.02 & 2 & 0.02 & 8 & 8 & 2 & 2 & $>256$ & 12 & 256 & & & $\begin{array}{l}\text { CTX-M15, } \\
\text { OXA-1 }\end{array}$ & $a a c\left(6^{\prime}\right)-I b-c r$ \\
\hline E.c9 & E. coli & 4 & 512 & 32 & 16 & 16 & 3 & 24 & $>256$ & 128 & $>256$ & $\begin{array}{l}\text { GM-K- } \\
\text { SXT-TET }\end{array}$ & 125 & $\begin{array}{l}\text { CTX-M15, } \\
\text { OXA-1 }\end{array}$ & $a a c\left(6^{\prime}\right)-I b-c r$ \\
\hline Тc9 & E. coli & 0.006 & 2 & 0.02 & 6 & 1.5 & 2 & 12 & $>256$ & 32 & $>256$ & & & $\begin{array}{l}\text { CTX-M15, } \\
\text { OXA-1 }\end{array}$ & $a a c\left(6^{\prime}\right)-I b-c r$ \\
\hline E.c64 & E. coli & 6 & 512 & 128 & 12 & 6 & 1.5 & 12 & $>256$ & 96 & $>256$ & $\begin{array}{c}\text { GM-K-TM- } \\
\text { SXT-TET }\end{array}$ & 125 & $\begin{array}{l}\text { CTX-M15, } \\
\text { OXA-1 }\end{array}$ & $\begin{array}{c}a a c\left(6^{\prime}\right)-I b- \\
c r l q n r S 1\end{array}$ \\
\hline Tc64 & E. coli & 0.094 & 8 & 0.5 & 6 & 4 & 1.5 & 12 & $>256$ & 48 & $>256$ & & & $\begin{array}{l}\text { CTX-M15, } \\
\text { OXA-1 }\end{array}$ & $\begin{array}{c}a a c\left(6^{\prime}\right)-I b- \\
c r l q n r S 1\end{array}$ \\
\hline K.p30 & K. pneumoniae & 0.012 & 2 & 0.02 & 8 & 8 & 1 & 4 & $>256$ & 64 & $>256$ & GM-TET & 125 & $\begin{array}{l}\text { CTX-M15, } \\
\text { SHV-1, } \\
\text { OXA-1 }\end{array}$ & $a a c\left(6^{\prime}\right)-I b-c r$ \\
\hline Тc30 & K. pneumoniae & 0.004 & 2 & 0.02 & 8 & 1 & 1 & 3 & $>256$ & 64 & $>256$ & & & $\begin{array}{l}\text { CTX-M15, } \\
\text { OXA-1 }\end{array}$ & $a a c\left(6^{\prime}\right)-I b-c r$ \\
\hline E.c1 & E. coli & $>32$ & 512 & 128 & 12 & 32 & 8 & 12 & $>256$ & 128 & $>256$ & & 125 & $\begin{array}{l}\text { SHV-5, } \\
\text { TEM-1b }\end{array}$ & $a a c\left(6^{\prime}\right)-I b-c r$ \\
\hline $\mathrm{Tc} 1$ & E. coli & 0.02 & 2 & 0.02 & 6 & 16 & 3 & 12 & $>256$ & 32 & 128 & GM-TM-K & & $\begin{array}{l}\text { SHV-5, } \\
\text { TEM-1b }\end{array}$ & $a a c\left(6^{\prime}\right)-I b-c r$ \\
\hline $\mathrm{K}_{12} \mathrm{~J}_{5}$ & E. coli & 0.006 & 2 & 0.02 & 0.5 & 0.5 & 0.75 & 0.75 & 0.5 & 0.5 & 0.5 & - & - & - & - \\
\hline
\end{tabular}

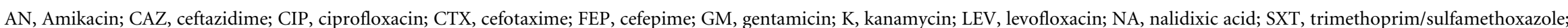
Tc, transconjugant; TET, tetracycline; TM, tobramycin.

${ }^{\star}$ TEM-1b, OXA-1 and SHV-1 are not ESBLs. 


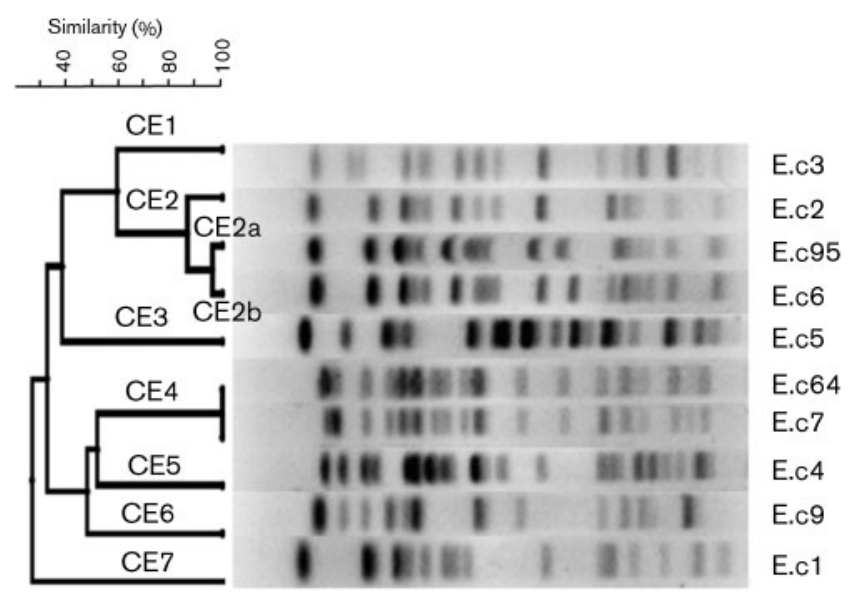

Fig. 1. Dendrogram produced by DendroUPGMA (a dendrogramconstruction utility) using the Dice similarity coefficient and UPGMA on the basis of the PFGE profiles of E. coli strains.

and $2(5.5 \%) \mathrm{K}$. pneumoniae gained their resistance by producing ESBLs. Third-generation cephalosporin resistance in non-ESBL producers $(27 \mathrm{E}$. coli and $6 \mathrm{~K}$. pneumoniae strains) could be due to some other resistance mechanism such as lack of permeation of porins and AmpC $\beta$-lactamase production (Mohamudha et al., 2010).

The prevalence of $1.3 \%$ ESBL-producing E. coli in the community found in this study is similar to that recorded in Spanish and French communities (1.4\%) (Arpin et al., 2009; Rodríguez-Baño et al., 2004) but lower than the 5.2\% observed in a Spanish multicentre study covering 15 microbiology laboratories in 2006 (Andreu et al., 2008). A study performed in Turkey showed a prevalence of $21 \%$ ESBL producers among E. coli causing communityacquired urinary tract infections during 2004 and 2005 (Yumuk et al., 2008). The study showed a much higher prevalence of ESBL-producing isolates among $K$. pneumoniae than among $E$. coli isolates.

Overall, the resistance patterns of ESBL-producing bacteria studied here were similar to those commonly described in other studies, i.e. the ESBL producers were resistant to different antibiotic families including - besides $\beta$-lactams fluoroquinolones, aminoglycosides and trimethoprim/sulfamethoxazole (Lahlou Amine et al., 2009; Minarini et al., 2007b; Mshana et al., 2009; Pitout et al., 2004; Sekhsokh et al., 2008; Shi et al., 2009), which contribute to the selection and persistence of multidrug-resistant ESBL strains and plasmids in both clinical and community settings (Cantón et al., 2008). Nevertheless, all CTX-Mproducing strains were susceptible to imipenem. However, the emergence of different types of carbapenemases could compromise the usefulness of this class of antibiotic (Walsh et al., 2005; Walther-Rasmussen \& Høiby, 2006).

We detected a variety of $\beta$-lactamases among the isolates of E. coli and K. pneumoniae, namely SHV-, CTX-M-,
OXA- and TEM-type enzymes. The CTX-M type was the most common ESBL in our setting. The predominance of CTX-M-15 indicates that this allele is now common in Morocco, as in other countries as a result of worldwide dissemination (Arpin et al., 2009; Minarini et al., 2007a; Woodford et al., 2007). These higher rates of CTX-M among total ESBL enzymes are most probably associated with high mobilization of the encoding genes. Barlow et al. (2008) found that $b l a_{\text {СтХ-м }}$ genes are mobilized to plasmids almost ten times more frequently than other class $\mathrm{A} \beta$-lactamases.

The co-existence of different $\beta$-lactamases genes within the same isolate, as detected in this study, has also been reported in other countries (Arpin et al., 2009; Woodford et al., 2007). The combination of $b l a_{\mathrm{CTX}-\mathrm{M}-15}+b l a_{\mathrm{OXA}-1}$ $+b l a_{\text {TEM-1b }}$ was reported in 30 strains from Portugal (Mendonça et al., 2007), and an association between $b l a_{\mathrm{SHV}-5}$ and $b l a_{\mathrm{TEM}-1 \mathrm{~b}}$ has been described in the Brazilian community (Minarini et al., 2007a).

The association of $b l a_{\text {CTX-M-15 }}$ and $b l a_{\text {OXA-1 }}$ in the same strain has also been reported in Portugal (Mendonça et al., 2007) and the USA (Hanson et al., 2008). Combined production of CTX-M and OXA enzymes by E. coli and K. pneumoniae improved resistance to $\beta$-lactamase inhibitors, presumably explaining their non-susceptibility to amoxicillin/clavulanate (Livermore \& Hawkey, 2005).

Despite the importance of ESBLs as a serious clinical problem for treatment of patients carrying ESBL-expressing $K$. pneumoniae, the clinical importance of non-ESBL enzymes is yet to be revealed. Among these non-ESBL enzymes we identified SHV-1, an instrinsic gene in K. pneumoniae. Co-expression of CTX-M enzymes and SHV-1 penicillinases in K. pneumoniae strains is becoming very common (Kiratisin et al., 2008; Romero et al., 2005).

Among the 12 ESBL-producing isolates with reduced susceptibility to fluoroquinolones, $q n r$ genes remained infrequent, with only two isolates carrying the qnrS1 gene. Interestingly, as noted by other authors in hospitals and community settings (Crémet et al., 2011; Jiang et al., 2008; Pitout et al., 2009), qnr genes were particularly recovered among K. pneumoniae isolates (1/2) compared with E. coli isolates $(1 / 10)$, despite the low number of $K$. pneumoniae isolates in our collection. Although based on a limited number of qnr-positive isolates, our results underlined the absence of QnrA determinants in our community, which contrasts with studies reporting the presence of $q n r B 1$ and qnrA genes notably in Kenyan and Nigerian communities (Kariuki et al., 2007; Soge et al., 2006).

The $a a c\left(6^{\prime}\right)$-Ib-cr gene occurred in ESBL-producing enterobacterial strains with a higher prevalence than $q n r$ genes. These results support previous findings suggesting a wider dissemination of AAC(6 $\left.6^{\prime}\right)$-Ib-cr than Qnr determinants, especially in multiple clones of $E$. coli carrying the $b l a_{\mathrm{CTX}-\mathrm{M}-15}$ gene (Pitout et al., 2009; Ruppé et al., 2009; Soge et al., 2006).

We noted the absence of the qepA gene among the studied strains. This new PMQR mechanism is still very rare, except 
in China where recent studies underlined the predominance of the qерA gene in enterobacterial strains isolated from food-producing animals (Ma et al., 2009). The now common combination of CTX-M-15, OXA-1, SHV-1 and TEM-1 $\beta$-lactamases and PMQR determinants $a a c\left(6^{\prime}\right)-I b-c r$ and $q n r S 1$ in a community K. pneumoniae strain (K.p18), as reported here, is, to our knowledge, a first.

Conjugation experiments were successful in only 7 of the 12 isolates. However, it should be noted that only broth matings were carried out in this study and not filter matings, and thus the transmissibility potential for the other five isolates could not be fully ascertained. In addition, the ceftazidime concentration used for transconjugant selection could be a limiting factor, although CTXM-15 ESBLs confer high-level resistance to ceftazidime (MIC range 64 to $>128 \mu \mathrm{g} \mathrm{ml}^{-1}$ ) (Younes et al., 2011).

In this study, gentamicin and tetracycline resistance were transferable by conjugation in most of the isolates tested. Isolates harbouring CTX-M-15 were resistant to cefepime, with most of them exhibiting an MIC $>64 \mu \mathrm{g} \mathrm{ml}^{-1}$. It has been demonstrated that CTX-M ESBLs hydrolyse cefepime with higher efficiency compared with other ESBL types (Lavollay et al., 2006; Mshana et al., 2009). Plasmid analysis revealed that the majority of the transconjugants harboured large plasmids of $\sim 125 \mathrm{~kb}$. Most previous studies have found plasmids ranging from 7 to $200 \mathrm{~kb}$ in association with CTXM-15 (Baudry et al., 2009; Mshana et al., 2009). These findings suggest that, in our setting, the CTX-M-15 allele was carried on large conjugative plasmids that were well adapted to, and constantly exchanged by, lateral gene transfer among the E. coli and K. pneumoniae isolates.

The $a a c\left(6^{\prime}\right)-I b-c r$ gene has been linked mainly to CTX-M15 isolates in various surveys, whereas qnr genes are mostly associated with enzymes from the CTX-M-9 or CTX-M-1 groups, reflecting the fact that genes encoding resistance to $\beta$-lactams and quinolones are located on the same plasmid and thus passed on together among different enterobacterial species (Jones et al., 2008; Nordmann \& Poirel, 2005). The $q n r$ family and $a a c\left(6^{\prime}\right)-I b-c r$ confer only low-level resistance, but their presence could potentially facilitate evolution of the bacterial host towards higher levels of resistance by mutational alterations in the target type II topoisomerases. In this study, five of the seven transconjugants harbouring $a a c\left(6^{\prime}\right)-I b-c r$ showed no elevation of ciprofloxacin MIC. Indeed, $a a c\left(6^{\prime}\right)-I b-c r$ alone confers a degree of resistance sufficiently low that the MIC might not distinguish organisms that carry it from those that do not (Robicsek et al., 2006). Recently, Harajly et al. (2010) described transconjugants with no elevation of MIC after the transfer of $a a c\left(6^{\prime}\right)-I b-c r$.

PFGE analysis was used to establish the genetic relatedness of the ESBL-producing E. coli strains. Using a similarity coefficient of 0.80 , we were able to establish seven different clusters (CE1-CE7) among the E. coli isolates (Fig. 1) and to suggest some evidence of genetic relatedness among some strains producing CTX-M-15. Pattern CE4 contained two E. coli isolates (E.c7 and E.c64). These isolates were from two different outpatient clinics, collected in two different geographical regions (Casablanca and El Jadida) and were obtained over a 2 year period, and hence are likely to represent distinct pockets of community-acquired clonally related strain types. Pattern CE2 contained three E. coli isolates (E.c2, E.c95 and E.c6). Although E.c2 and E.c6 were isolated in the same city (Casablanca), they originated from two different patients who had contracted urinary tract infections in 2006 and 2005, respectively. These isolates showed $88 \%$ similarity with E.c95 collected in El Jadida city in 2008 and hence are clonally related. Various factors may have contributed to this dissemination, including the proximity of the population areas and/or inadequate antibiotic use. In contrast, the other five isolates (E.c3, E.c5, E.c4, E.c9 and E.c1) produced different PFGE digest patterns, indicating that they were isolates from distinct and unrelated sources of infection in their respective communities. Studies from Spain and the UK, also using PFGE, have shown that most E. coli producing CTX-M enzymes from the community are not clonally related. However, the UK study did suggest some evidence of genetic relatedness among strains producing CTX-M-1 (Pitout et al., 2005a, b).

The production of similar TEM and CTX-M-type enzymes in various genetically related strains and in isolates from distant regions suggests horizontal transfer of the corresponding genes. Isolates of profile type CE4 expressed CTXM-15 and OXA-1 enzymes and were multidrug-resistant. Isolates of profile subtype $\mathrm{CE} 2 \mathrm{~b}$ were also multidrug resistant and expressed CTX-M, OXA and TEM enzymes.

In conclusion, this report offers an insight into the current prevalence and molecular types of ESBL-producing organisms in Moroccan community settings, contributing to a better understanding of the epidemiology of these enzymes at local and national levels. Our results indicate that a variety of ESBL producers are present in outpatient settings and indicate the spread of the CTX-M-15 type among Enterobacteriaceae isolates, and the occurrence of clonal and polyclonal dissemination of ESBL-producing strains in the community. In addition, we have reported for what is to the best of our knowledge the first time the association of bla $a_{\mathrm{CTX}-\mathrm{M}-15}, q n r S 1$ and $a a c\left(6^{\prime}\right)-\mathrm{Ib}-\mathrm{cr}$ in a community K. pneumoniae strain and in E. coli strains in a North African country. Our results emphasize the necessity for adequate screening of ESBL-producing strains in Moroccan hospitals and community environments, together with efforts to promote the judicious use of antibiotics and to prohibit their sale without prescription.

\section{ACKNOWLEDGMENTS}

The authors thank Professor Patrice Courvalin (Institut Pasteur, Paris, France) for kindly providing the positive-control strains. They also thank the private medical analysis laboratories for providing the bacterial isolates. 


\section{REFERENCES}

Andreu, A., Planells, I. \& Grupo Cooperativo Español para el Estudio de la Sensibilidad Antimicrobiana de los Patógenos Urinario (2008). [Etiology of community-acquired lower urinary infections and antimicrobial resistance of Escherichia coli: a national surveillance study]. Med Clin (Barc) 130, 481-486 (in Spanish).

Arpin, C., Quentin, C., Grobost, F., Cambau, E., Robert, J., Dubois, V., Coulange, L. \& André, C. on behalf of the Scientific Committee of ONERBA (2009). Nationwide survey of extended-spectrum $\beta$ lactamase-producing Enterobacteriaceae in the French community setting. J Antimicrob Chemother 63, 1205-1214.

Barlow, M., Reik, R. A., Jacobs, S. D., Medina, M., Meyer, M. P., McGowan, J. E., Jr \& Tenover, F. C. (2008). High rate of mobilization for $b l a_{\text {CTX-M }}$ s. Emerg Infect Dis 14, 423-428.

Baudry, P. J., Nichol, K., DeCorby, M., Lagacé-Wiens, P., Olivier, E., Boyd, D., Mulvey, M. R., Hoban, D. J. \& Zhanel, G. G. (2009). Mechanisms of resistance and mobility among multidrug-resistant CTX-M-producing Escherichia coli from Canadian intensive care units: the 1st report of QepA in North America. Diagn Microbiol Infect Dis 63, 319-326.

Bourjilat, F., Dersi, N., Bouchrif, B., Amarouch, H. \& Timinouni, M. (2009). [Antibiotic resistance profile of community acquired uropathogenic E. coli in Morocco]. Eur J Sci Res 38, 57-62 (in French).

Cantón, R., Novais, A., Valverde, A., Machado, E., Peixe, L., Baquero, F. $\&$ Coque, T. M. (2008). Prevalence and spread of extended-spectrum $\beta$-lactamase-producing Enterobacteriaceae in Europe. Clin Microbiol Infect 14 (Suppl. 1), 144-153.

Coque, T. M., Novais, A., Carattoli, A., Poirel, L., Pitout, J., Peixe, L., Baquero, F., Cantón, R. \& Nordmann, P. (2008). Dissemination of clonally related Escherichia coli strains expressing extended-spectrum $\beta$-lactamase CTX-M-15. Emerg Infect Dis 14, 195-200.

Crémet, L., Caroff, N., Dauvergne, S., Reynaud, A., Lepelletier, D. \& Corvec, S. (2011). Prevalence of plasmid-mediated quinolone resistance determinants in ESBL Enterobacteriaceae clinical isolates over a 1-year period in a French hospital. Pathol Biol (Paris) 59, $151-156$.

Durmaz, R., Otlu, B., Koksal, F., Hosoglu, S., Ozturk, R., Ersoy, Y., Aktas, E., Gursoy, N. C. \& Caliskan, A. (2009). The optimization of a rapid pulsed-field gel electrophoresis protocol for the typing of Acinetobacter baumannii, Escherichia coli and Klebsiella spp. Jpn J Infect Dis 62, 372-377.

Guessennd, N., Bremont, S., Gbonon, V., Kacou-Ndouba, A., Ekaza, E., Lambert, T., Dosso, M. \& Courvalin, P. (2008). [Qnr-type quinolone resistance in extended-spectrum $\beta$-lactamase producing enterobacteria in Abidjan, Ivory Coast]. Pathol Biol (Paris) 56, 439-446 (in French).

Hanson, N. D., Moland, E. S., Hong, S. G., Propst, K., Novak, D. J. \& Cavalieri, S. J. (2008). Surveillance of community-based reservoirs reveals the presence of CTX-M, imported AmpC, and OXA-30 $\beta$-lactamases in urine isolates of Klebsiella pneumoniae and Escherichia coli in a U.S. community. Antimicrob Agents Chemother 52, 3814-3816.

Harajly, M., Khairallah, M. T., Corkill, J. E., Araj, G. F. \& Matar, G. M. (2010). Frequency of conjugative transfer of plasmid-encoded ISEcp1 - bla $a_{\mathrm{CTX}-\mathrm{M}-15}$ and $a a c\left(6^{\prime}\right)$-lb-cr genes in Enterobacteriaceae at a tertiary care center in Lebanon - role of transferases. Ann Clin Microbiol Antimicrob 9, 19.

labadene, H., Messai, Y., Ammari, H., Ramdani-Bouguessa, N., Lounes, S., Bakour, R. \& Arlet, G. (2008). Dissemination of ESBL and Qnr determinants in Enterobacter cloacae in Algeria. J Antimicrob Chemother 62, 133-136.

Jiang, Y., Zhou, Z., Qian, Y., Wei, Z., Yu, Y., Hu, S. \& Li, L. (2008). Plasmid-mediated quinolone resistance determinants qnr and $a a c\left(6^{\prime}\right)$-Ib-cr in extended-spectrum $\beta$-lactamase-producing Escherichia coli and Klebsiella pneumoniae in China. J Antimicrob Chemother 61, 1003-1006.

Jones, G. L., Warren, R. E., Skidmore, S. J., Davies, V. A., Gibreel, T. \& Upton, M. (2008). Prevalence and distribution of plasmid-mediated quinolone resistance genes in clinical isolates of Escherichia coli lacking extended-spectrum $\beta$-lactamases. J Antimicrob Chemother 62, 1245-1251.

Kariuki, S., Revathi, G., Corkill, J., Kiiru, J., Mwituria, J., Mirza, N. \& Hart, C. A. (2007). Escherichia coli from community-acquired urinary tract infections resistant to fluoroquinolones and extended-spectrum $\beta$-lactams. J Infect Dev Ctries 1, 257-262.

Kiratisin, P., Apisarnthanarak, A., Laesripa, C. \& Saifon, P. (2008). Molecular characterization and epidemiology of extended-spectrum$\beta$-lactamase-producing Escherichia coli and Klebsiella pneumoniae isolates causing health care-associated infection in Thailand, where the CTX-M family is endemic. Antimicrob Agents Chemother 52, 2818-2824.

Lahlou Amine, I., Chegri, M. \& L'Kassmi, H. (2009). [Epidemiology and antibiotic resistance of Enterobacteriaceae isolated in urinary tract infections at the Moulay-Ismail Military Hospital of Meknes]. Antibiotiques 11, 90-96 (in French).

Lavollay, M., Mamlouk, K., Frank, T., Akpabie, A., Burghoffer, B., Ben Redjeb, S., Bercion, R., Gautier, V. \& Arlet, G. (2006). Clonal dissemination of a CTX-M-15 $\beta$-lactamase-producing Escherichia coli strain in the Paris area, Tunis, and Bangui. Antimicrob Agents Chemother 50, 2433-2438.

Livermore, D. M. \& Hawkey, P. M. (2005). CTX-M: changing the face of ESBLs in the UK. J Antimicrob Chemother 56, 451-454.

Ma, J., Zeng, Z., Chen, Z., Xu, X., Wang, X., Deng, Y., Lü, D., Huang, L., Zhang, Y. \& other authors (2009). High prevalence of plasmidmediated quinolone resistance determinants $q n r, a a c\left(6^{\prime}\right)-I b-c r$, and qерA among ceftiofur-resistant Enterobacteriaceae isolates from companion and food-producing animals. Antimicrob Agents Chemother 53, 519-524.

Macrina, F. L., Kopecko, D. J., Jones, K. R., Ayers, D. J. \& McCowen, S. M. (1978). A multiple plasmid-containing Escherichia coli strain: convenient source of size reference plasmid molecules. Plasmid 1, 417-420.

Mendonça, N., Leitão, J., Manageiro, V., Ferreira, E. \& Caniça, M. (2007). Spread of extended-spectrum $\beta$-lactamase CTX-M-producing Escherichia coli clinical isolates in community and nosocomial environments in Portugal. Antimicrob Agents Chemother 51, 1946-1955.

Minarini, L. A., Camargo, I. L., Pitondo-Silva, A. \& Darini, A. L. (2007a). Multilocus sequence typing of uropathogenic ESBLproducing Escherichia coli isolated in a Brazilian community. Curr Microbiol 55, 524-529.

Minarini, L. A., Gales, A. C., Palazzo, I. C. \& Darini, A. L. (2007b). Prevalence of community-occurring extended spectrum $\beta$-lactamaseproducing Enterobacteriaceae in Brazil. Curr Microbiol 54, 335-341.

Mohamudha, P. R., Harish, B. N. \& Parija, S. C. (2010). AmpC $\beta$ lactamases among Gram negative clinical isolates from a tertiary hospital, South India. Braz J Microbiol 41, 596-602.

Mshana, S. E., Imirzalioglu, C., Hossain, H., Hain, T., Domann, E. \& Chakraborty, T. (2009). Conjugative IncFI plasmids carrying CTX-M15 among Escherichia coli ESBL producing isolates at a university hospital in Germany. BMC Infect Dis 9, 97.

Nordmann, P. \& Poirel, L. (2005). Emergence of plasmid-mediated resistance to quinolones in Enterobacteriaceae. $J$ Antimicrob Chemother 56, 463-469.

Périchon, B., Courvalin, P. \& Galimand, M. (2007). Transferable resistance to aminoglycosides by methylation of G1405 in 16S rRNA 
and to hydrophilic fluoroquinolones by QepA-mediated efflux in Escherichia coli. Antimicrob Agents Chemother 51, 2464-2469.

Pitout, J. D., Hanson, N. D., Church, D. L. \& Laupland, K. B. (2004). Population-based laboratory surveillance for Escherichia coli-producing extended-spectrum $\beta$-lactamases: importance of community

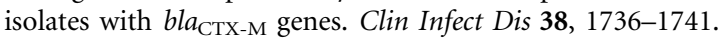

Pitout, J. D., Gregson, D. B., Church, D. L., Elsayed, S. \& Laupland, K. B. (2005a). Community-wide outbreaks of clonally related CTX-M-14 $\beta$-lactamase-producing Escherichia coli strains in the Calgary health region. J Clin Microbiol 43, 2844-2849.

Pitout, J. D., Nordmann, P., Laupland, K. B. \& Poirel, L. (2005b). Emergence of Enterobacteriaceae producing extended-spectrum $\beta$ lactamases (ESBLs) in the community. J Antimicrob Chemother 56, 52-59.

Pitout, J. D., Campbell, L., Church, D. L., Gregson, D. B. \& Laupland, K. B. (2009). Molecular characteristics of travel-related extendedspectrum- $\beta$-lactamase-producing Escherichia coli isolates from the Calgary health region. Antimicrob Agents Chemother 53, 2539-2543.

Reinert, R. R., Low, D. E., Rossi, F., Zhang, X., Wattal, C. \& Dowzicky, M. J. (2007). Antimicrobial susceptibility among organisms from the Asia/Pacific Rim, Europe and Latin and North America collected as part of TEST and the in vitro activity of tigecycline. J Antimicrob Chemother 60, 1018-1029.

Robicsek, A., Jacoby, G. A. \& Hooper, D. C. (2006). The worldwide emergence of plasmid-mediated quinolone resistance. Lancet Infect Dis 6, 629-640.

Rodríguez-Baño, J., Navarro, M. D., Romero, L., Martínez-Martínez, L., Muniain, M. A., Perea, E. J., Pérez-Cano, R. \& Pascual, A. (2004). Epidemiology and clinical features of infections caused by extendedspectrum $\beta$-lactamase-producing Escherichia coli in nonhospitalized patients. J Clin Microbiol 42, 1089-1094.

Rodríguez-Baño, J., Alcalá, J., Cisneros, J. M., Grill, F., Oliver, A., Horcajada, J. P., Tórtola, T., Mirelis, B., Navarro, G. \& other authors (2009). Escherichia coli producing SHV-type extended-spectrum $\beta$-lactamase is a significant cause of community-acquired infection. J Antimicrob Chemother 63, 781-784.

Romero, L., López, L., Rodríguez-Baño, J., Ramón Hernández, J., Martínez-Martínez, L. \& Pascual, A. (2005). Long-term study of the frequency of Escherichia coli and Klebsiella pneumoniae isolates producing extended-spectrum $\beta$-lactamases. Clin Microbiol Infect 11, 625-631.

Ruppé, E. (2010). [Epidemiology of expanded-spectrum $\beta$-lactamases: the rise of CTX-M]. Antibiotiques 12, 3-16 (in French).

Ruppé, E., Woerther, P. L., Diop, A., Sene, A. M., Da Costa, A., Arlet, G., Andremont, A. \& Rouveix, B. (2009). Carriage of CTX-M-15producing Escherichia coli isolates among children living in a remote village in Senegal. Antimicrob Agents Chemother 53, 3135-3137.

Sekhsokh, Y., Chadli, M. \& El Hamzaoui, S. A. (2008). [Frequency and antibiotic susceptibility of bacteria identified in urine]. Med Mal Infect 38, 324-327 (in French).

Shi, W. F., Zhou, J. \& Qin, J. P. (2009). Transconjugation and genotyping of the plasmid-mediated AmpC $\beta$-lactamase and extended-spectrum $\beta$-lactamase genes in Klebsiella pneumoniae. Chin Med J (Engl) 122, 1092-1096.

Soge, O. O., Adeniyi, B. A. \& Roberts, M. C. (2006). New antibiotic resistance genes associated with CTX-M plasmids from uropathogenic Nigerian Klebsiella pneumoniae. J Antimicrob Chemother 58, 1048-1053.

Walsh, T. R., Toleman, M. A., Poirel, L. \& Nordmann, P. (2005). Metallo- $\beta$-lactamases: the quiet before the storm? Clin Microbiol Rev 18, 306-325.

Walther-Rasmussen, J. \& Høiby, N. (2006). OXA-type carbapenemases. J Antimicrob Chemother 57, 373-383.

Woodford, N., Kaufmann, M. E., Karisik, E. \& Hartley, J. W. (2007). Molecular epidemiology of multiresistant Escherichia coli isolates from community-onset urinary tract infections in Cornwall, England. J Antimicrob Chemother 59, 106-109.

Younes, A., Hamouda, A., Dave, J. \& Amyes, S. G. (2011). Prevalence of transferable $b l a_{\mathrm{CTX}-\mathrm{M}-15}$ from hospital- and community-acquired Klebsiella pneumoniae isolates in Scotland. J Antimicrob Chemother 66, 313-318.

Yumuk, Z., Afacan, G., Nicolas-Chanoine, M. H., Sotto, A. \& Lavigne, J. P. (2008). Turkey: a further country concerned by communityacquired Escherichia coli clone O25-ST131 producing CTX-M-15. J Antimicrob Chemother 62, 284-288. 